\title{
Determination of The Cognitive Structures of Year Secondary School Students Through Word Association Test Techniques
}

\author{
Gülcan POLAT* \\ Teacher at Private Erbaa Pi Analitik Course, Tokat, Türkiye \\ Received : 31.05.2012 \\ Accepted : 31.05.2013
}

\begin{abstract}
The purpose of this study was to determine the cognitive structures and to reveal the retention of knowledge occurring in a class of year 9 secondary school students after applying certain types of education. The study was conducted during the academic year of 2008-2010 with 48 students studying at a private high school located in the municipality of Istanbul using a Word Association Test (WAT). Two weeks after the having been taught a certain item and one year after teaching it the students were subjected to the WAT test. After completion of the test, a mind map was drawn from the results using the frequency tables prepared for the answers given by the students to the selected key concepts. Research results showed that the responses that the students gave shortly after the education involved more scientific expressions and the number of words used during the responses was higher, while their response rates showed a decrease both in number and frequency of use of scientific terminology used by the same students after one year
\end{abstract}

Key words: word association test, environmental problems, environmental education.

DOI No: http://dx.doi.org/10.12973/nefmed155

\section{Summary}

\section{Introduction}

İnanç and Kurgan (2000) have stated that one of the main reasons that environmental problems occurring nowadays in the world is the lack of information and awareness. They also stated that those individuals lacking education or consciousness are unable to comprehend the fact that the world they are living in shall also be used by others after them, whereas the environment is not a legacy left to us from the past, but a trust, which should be handed over intact to future generations. In a similar way Tombul (2006) has stated that the continuation of our existence in the world may only be possible by safeguarding the sustainability of the natural wealth of our environment. To that goal, it is necessary to raise

\footnotetext{
* Corresponding author: Dr. Gülcan POLAT, Private Erbaa Pi Analitik Course, TOKAT, TURKEY.

E-mail: gulcanpolat@yahoo.com
} 
awareness in those individuals, institutions and organizations that are continuously dealing with the environmental concerns. The need for individuals who are sensitive to environmental issues and who behave in a conscious manner increases every day, as well as it is clear that such need can only be met through target specific environmental education.

The purpose of this study consists of revealing i) the cognitive structures after such education, and ii) the permanence of the change in the environment-related cognitive structures of the students, which occurred with the same concepts during the post- educational period after one year. Such determination was measured quantitatively by applying a Word Association Test (WAT) to a class of year 9 secondary school students which was related to the unit "Conscious Individuals-Habitable Environment" of a biology course.

\section{Methodology}

After teaching the unit to the students for two weeks, a Word Association Test (WAT) was given to them. After one year, when the students studied in year 10 , the same Word Association Test (WAT) was given to them again.. After Word Association Test (WAT) application, the resulting answers of each student for key concepts were evaluated . Frequency charts showing how many answers had been produced and how many of these answers repeated the key concepts, were arranged. The frequency charts which were produced according to the Word Association Test (WAT) that was applied after one year can be found in attachment 1 and 2. Because the original frequency charts would be too long, only a part of the frequency charts is shown. After evaluating the frequency charts, two separate mind maps for both results were prepared. The Break Point Method for the preparation of mind maps presented (1999) by Bahar and et.al was used.

\section{Discussion and Conclusion}

In this study, the results of WAT applied one year after the education; showed that in order to express their knowledge after one year, the students used terms encountered in their daily lives rather than scientific expressions. It was determined that the students utilized more scientific vocabulary and scientifically accurate responses during the pre tests rather than the final one. When we compared the pre-test mind maps with the final-test concept maps, drawn up in accordance with the frequency tables it showed that even taking into consideration either the key concepts or the responses associated to such key concepts as well as the inter connections between them a decline had occurred over time, in other words, the results have demonstrated that knowledge of the concepts had been forgotten. 
In line with the results obtained in this study, the result of environmental education as applied to the year 9 class made it clear that students had not retained sufficient information relating to the environment. Examining the mind map after the teaching process is obvious that even students who were in the interval KN 10-14 could not make links between key notions and answers. The frequency of use of key scientific terminology was noticeably low. For example, important concepts such as ozone layer depletion, greenhouse effects and radiation pollution which had been explicitly taught to the year 9 students were not reproduced when asked about what would constitute an "environmentally aware individual concerned about a livable environment''. In addition, it could be shown that any information acquired as a result of teaching was not lasting and students forgot the concepts shortly after receiving the teaching. After teaching, not retaining some of the information acquired through teaching over a period of time was an expected outcome but the degree of non-detainment was far higher than predicted. In accordance with these results, it may be said that any environmental training provided with regard to the environment and environmental problems did not significantly change the viewpoints of the students, nor did it make them more environmentally conscious and any awareness gained did not result in a permanent change in real terms. These results show similarity with other large scale scientific studies emphasizing that the present form of environmental training applied in Turkey is not sufficient to produce more environmentally conscious individuals (Ünal \& Dımışkı, 1999; Bahar, 2000; Özdemir, Yıldız, Ocaktan \& Sarışen, 2004; Yılmaz and et.al, 2002; Özdemir 2007).

In conclusion the results of this study show that Word Association Tests (WAT) are a very suitable tool for identifying and gauging the actual learning of students over a period of time. Teachers could use the results of the WAT tests in order to predict how much previous knowledge students will retain from earlier teaching, and for revisiting these concepts as part of a spiral curriculum. This can aid teachers in their lessons planning, from pre-teaching to post- teaching. Thus, preparing for lessons would become easier and a teacher could reach larger groups within a shorter time. 


\title{
9. Sınıf Öğrencilerinin Çevreye İlişkin Bilişsel Yapılarının Kelime İlişkilendirme Test Tekniği ile Tespiti
}

\author{
Gülcan POLAT ${ }^{\dagger}$ \\ *özel Erbaa Pi Analitik Dershaneside Öğretmen, Tokat, TÜRKİYE \\ Makale Gönderme Tarihi: 31.05.2013 Makale Kabul Tarihi: 31.05.2013
}

\begin{abstract}
Özet - Bu çalışma ortaöğretim 9. sınıf öğrencilerinin uygulanan öğretim sonrasında bilişsel yapılarındaki bilgilerin tespiti ve kalıcılığını açığa çıkarmak amacı ile yapılmıştır. Çalışma, Kelime İlişkilendirme Testi (KİT) kullanılarak 2008-2010 öğretim yıllarında İstanbul ilinde özel bir lisede öğrenim gören 48 öğrenci ile yürütülmüştür. Öğrencilere öğretimden iki hafta sonra ve bir yıl sonra KİT uygulanmış, öğrencilerin seçilen anahtar kavramlara verdikleri cevaplardan hazırlanan frekans tablosu kullanılarak zihin haritaları çizilmiştir. Araştırma sonuçları; öğretimden sonra öğrencilerin cevaplarının daha çok bilimsel ifade içerdiğini ve kullandıkları cevap kelime sayısının fazla olduğunu, bir yıl sonra ise bu oranın azaldığını göstermektedir. Zihin haritaları öğrencilerin hem öğretim sonrasında hem de bir yıl sonra kavramlar arasındaki ilişkiyi tam bir ağ biçiminde algılamadıklarını ortaya koymuştur. Araştırma sonuçları; kelime ilişkilendirme testlerinin eğitimsel bir araç olarak nasıl kullanılabileceği ve sonuçların çevre eğitimi açısından önemi yönünden irdelenmiştir.
\end{abstract}

Anahtar kelimeler: Kelime ilişkilendirme testi, çevre, çevre eğitimi, bilişsel yapı.

\section{Giriş}

İnsanların yaşam standartlarının giderek yükselmesi ve dünya nüfusundaki hızlı artış doğal kaynaklar üzerindeki baskıyı arttırmıştır. Artan nüfusun doyurulması, giydirilmesi ve barındırılabilmesi kaynak kullanımını hızlandırarak beraberinde önemli çevre sorunlarını ortaya çıkarmıştır (Doğan, 1997). 1970, 1980 ve 1990’lı yıllar, tüm insanlığın, gelişmiş-az gelişmiş ülke ayrımı olmaksızın, yeni bir ortak sorunla karşılaştığı ya da bu sorunun bilincine vardığı yıllardır. İnsanlığın bu ortak sorunu, en geniş anlamıyla çevrenin hızlı bir şekilde bozulması, çevre değerlerinin yozlaşması ya da yok olup gitme tehlikesidir (Keleş, 1997).

İnanç ve Kurgan (2000), bugün dünyada ortaya çıkan çevre sorunlarının en temel sebeplerinden birinin, bilgi edinme ve bilinçlenmede karşılaşılan eksiklikler olduğunu

\footnotetext{
†'Iletişim: Gülcan POLAT, Dr., Özel Erbaa Pi Analitik Dershanesi, Tokat, TÜRKIYE.

E-Posta: gulcanpolat@yahoo.com
} 
belirtmişlerdir. Eğitilmemiş ve bilinçlenmemiş bireylerin, yaşadığı dünyayı kendisinden sonra başkalarının da kullanacağını idrak edemediğini, çevrenin bize geçmişten bırakılan bir miras değil, gelecek nesillere devredilmesi gereken bir emanet olduğunu belirtmişlerdir. Benzer bir şekilde Tombul (2006), ulusların varlıklarını devam ettirebilmesinin ancak doğal zenginliklerin sürdürebilirliğini garanti etmekle mümkün olabileceğini belirtmiştir. Doğayla sürekli alışveriş içinde bulunan bireylerin, kurum ve kuruluşların eğitilmesi ve bireylere eğitimle çocukluktan itibaren çevre duyarlılığı kazandırılması ile mümkün görülmektedir. Günümüzde çevreye duyarlı ve bilinçli davranabilen bireylere duyulan gereksinimin her geçen gün arttığı söylenebilir. Bu gereksinimin ise ancak çevre eğitimiyle giderilmesinin mümkün olduğu iddia edilebilir.

Fen ve çevre eğitimi ile ilgili araştırmalarda bireylerin sahip oldukları bilgi ve kavramların anlaşılma düzeylerini açığa çıkarmak amacı ile farklı yöntem ve tekniklerin kullanıldı̆̆ı görülmektedir. Bu yöntem ve tekniklerden ön plana çıkanlar çizim, mülakat, kavram haritası, yazılı cevap gerektiren testler, kelime ilişkilendirme testi, tahmin- gözlemaçıklamadır (White \& Gunstone, 2000; Bahar \& Özatl1, 2003; Bahar, Johnstone \& Sutcliffe, 1999; Özatlı, 2006; Özcan, 2010; Yalvaç, 2008).

Kelime ilişkilendirme, insanların kavramlar arasında kurduğu ilişkileri açığa çıkarmak için geliştirilen bir tekniktir. Kavramlar, konular içinde yer alan birimler olabileceğinden, kelime ilişkilendirme tekniğgi sadece kavramların değil, bir disiplinin, durumların ve hatta kişilerin dahi nasıl anlaşıldığını ölçmek amacı ile kullanılabilir (Atasoy, 2004).

Bahar ve diğerlerinin (1999) araştırmalarından sonra KİT, anlamayı açı̆̆a çıkarma ve bilimsel araştırmalarda daha fazla kullanılmaya başlanmıştır. Literatürde geçmişten bu yana birçok araştırmacının bu metodu kullandığı görülmektedir (Shavelson, 1974; Bahar ve digerleri 1999; Bahar \& Özatl1, 2003; Özatl1, 2006; Yalvaç, 2008).

Bu metotta, öğrenci belli zaman dilimi içerisinde herhangi bir konu ile ilgili verilen bir anahtar kavramın, aklına getirdiği kavramları cevap olarak verir. Ayrıca öğrencinin uzun dönemli hafızasından herhangi bir anahtar kavrama verdiği sıralı cevabın bilişsel yapıdaki kavramlar arasında bağlantıları ortaya koyduğu ve anlamsal yakınlığı gösterdiği farz edilir. Anlamsal yakınlık veya anlamsal mesafe etkisine göre anlamsal bellekte iki kavram birbirine mesafe açısından ne kadar yakın ise o kadar sıkı ilişkidedir ve hatırlama esnasında da zihinsel araştırma daha çabuk olacağından her iki kavramla ilgili cevap daha hızlı verilecektir (Bahar \& Özatl1, 2003). 
Kempa ve Nicholls (1983), çalışmalarında öğrencilerin bilişsel yapılarındaki kavramlar ile kimya ile ilgili problem çözme yeteneklerini karşılaştırmışlardır. Öğrencilere önce KİT, daha sonrada KİT’teki anahtar kavramlarla ilgili çoktan seçmeli bir test uygulamıştır. Çalışmaları sonucunda, öğrencilerin KİT'lerinde iletişim kuramadıkları veya cevap üretmedikleri kavramlarla ilgili çoktan seçmeli test sorularını da cevaplayamadıklarını saptamışlardır.

Bahar ve diğerleri (1999), Glasgow Üniversitesi 1. sınıfta öğrenim gören 280 biyoloji öğrencisi üzerinde genetik alanında konu anlatımı sonrası KİT uygulamıştır. Bu çalışmada, öğrencilerin verilen on anahtar kavram ve ilgili diğer kavramlar arasındaki ilişkiyi haritalamak amacı ile cevap frekansları ve ilişki katsayı değerleri kullanılmıştır. Çalışma sonuçları, öğrencilerin verilen anahtar kavramlara birçok cevap üretmelerine karşın bu kavramları birbiri içerisine girmiş, ilişkili bir ağ olarak göremediklerini ortaya koymuştur. Daha da önemlisi bu kavramlar arasında tam bir ağ oluşmamasına rağmen öğrencilerin sınavlardan yüksek not aldığı tespit edilmiştir. Yapılan araştırma sonucu sınavlarda öğretmenin çoktan seçmeli testler kullandığg ve soruların birçoğunun kavramlar arası ilişkileri kontrol etmediği, aksine bilişsel yapıda her biri ayrı adacık şeklinde olan kavramları test ettiği görülmüştür.

Cardelini ve Bahar (2000), kimya mühendisliği bölümü 1. sınıfta öğrenim gören 86 öğrenci ile bir çalışma yapmışlardır. Çalışmalarında kelime ilişkilendirme testini bu öğrencilerin genel kimya ile ilgili kavramlar hakkında bilişsel yapısını haritalamak amacı ile kullanmışlardır. Konu anlatımı öncesi ve sonrasında uygulanan KİT sonuçları, öğrencilerin konu anlatımı sonrasında belirlenen anahtar kavramlara verdikleri cevapların ve ilişkilendirdikleri cevap kelime sayısının arttı̆̆ını göstermiştir. Ancak, haritalama sonuçları incelendiğinde öğrencilerin büyük çoğunluğunun anahtar kavramlar ile cevap kelimelerini bir ağ şeklinde göremediklerini ortaya koymaktadır.

Bahar ve Özatlı (2003), Balıkesir ilinde iki farklı kız meslek lisesinde öğrenim gören 60 öğrenci ile bir çalışma yapmışlardır. Bu çalışmada canlıların temel bileşenleri ünitesi ile ilgili öğrencilerin bilişsel yapılarındaki değişimi açığa çıkarmak amacı ile öğretim öncesinde ve sonrasında KİT uygulamışlardır. Öğrencilerin seçilen anahtar kavramlara verdikleri cevaplara göre frekans tablosu hazırlamışlar, bu frekans tablosunu kullanarak da bir zihin haritası oluşturmuşlardır. Araştırmaları sonucunda, öğrencilerin ön bilgilerinin konu ile çok yakın ilgisi olmayan geniş bir alana yayıldığını, son testlerde ön testlere göre daha bilimsel ve 
daha fazla cevap ürettiklerini saptamışlardır. Zihin haritaları öğrencilerin kavramlar arasındaki ilişkiyi tam bir ağ biçiminde algılamadıklarını göstermiştir.

Yalvaç (2008) yüksek lisans tezinde işbirlikli öğrenme yaklaşımının, fen ve teknoloji öğretmen adaylarının çevreye ilişkin zihinsel yapılarındaki kavramlar arası ilişkilere etkisi olup olmadığını araştırmak amacı ile öğretim öncesi ve sonrasında KİT kullanmıştır. Çalışma sonucunda, öğretim sonrasında KİT'te yer alan cevap kelime çeşidinin azalmasına rağmen konuyla doğrudan bağlantılı cevap kelime sayısının arttığı tespit edilmiş; frekans tablolarına göre hazırlanan zihin haritalarında, işbirlikli öğrenme yaklaşımının öğretmen adaylarının, çevre ve çevre sorunlarına yönelik bilişsel yapılarında dallanmış ve ağsı bir yapılandırma saptanmıştır. Bu sonuçlar doğrultusunda öğretmen adaylarının çevreye yönelik bilgilerinde ve bilinçlerinde olumlu bir etki meydana geldiği belirlenmiştir.

Daha önce yapılan bilimsel araştırmalar incelendiğinde, araştırmacıların KİT tekniğini daha çok öğrencilerin öğretim öncesinde ve sonrasında bilişsel yapılarını tespit etmek ve öğretimle bilişsel yapılarında meydana gelen değişimi açığa çıkarmak amacı ile kullandığı görülmektedir. Yapılan bu araştırmalarda elde edilen sonuçlara ek olarak öğrencilerin öğretim sonrasında bilişsel yapılarında meydana gelen değişim ve kalıcılığının tespit edilmesinde de KİT tekniğinin etkili bir şekilde kullanılabileceği düşünülmektedir.

\section{Araştırmanın Amacı}

Yaşanılabilir bir çevrenin oluşturulabilmesi ve sürekliliğinin sağlanabilmesi için çevre eğitimine önem verilmesi gerektiği önemli bir gerçektir. Bireylerde çevre ile ilgili tutum ve davranışların oluşturulmasında ilköğretim ve ortaöğretimde uygulanan çevre eğitiminin önemli olduğu açıktır.

Buradan hareketle araştırmanın amacı, KİT tekniği ile ortaöğretim 9. sınıf biyoloji dersi "bilinçli birey yaşanabilir çevre" ünitesi ile ilgili öğrencilerin i)öğretim sonrasındaki bilişsel yapılarını ve ii) bir yıl sonrasında aynı kavramlar ile ilgili öğretim sonrasında bilişsel yapılarında yer alan bilgilerin kalıcılı̆̆ını tespit etmektir.

\section{Yöntem}

\section{Çalışma Grubu}

$\mathrm{Bu}$ araştırmanın çalışma grubunu İstanbul ili Özel Bostancı Doğa Kolejinde öğrenim gören 48 9. sınıf öğrencisi oluşturmaktadır. OKS (Ortaöğretim Kurumları Sınavı) puanları birbirine yakın iki sınıfta bulunan öğrenciler çalışma grubuna dahil edilerek, çalışma 
grubunda yer alan öğrencilerin öğretim öncesinde bilişsel yapılarının benzer olmasına dikkat edilmiştir.

\section{Veri Toplama Aracı ve Verilerin Analizi}

$\mathrm{Bu}$ araştırmada öğrencilerin öğretim sonrasında bilişsel yapıları ve bilişsel yapılarındaki bilgilerin kalıcılığını tespit etmek amacı ile Kelime İlişkilendirme Testi (KİT) kullanılmıştır.

Kelime ilişkilendirme testini oluşturmak amacı ile "bilinçli birey yaşanılabilir çevre" ünitesinde yer alan 6 adet anahtar kavram (konu için en önemli olan kavramlar yani konunun üzerine bina edildiği kavramlar) seçilmiştir. Anahtar kavramların seçimi bir "alan uzmanı" ile birlikte yapılmıştır. Daha sonra her kavram bir sayfaya gelecek şekilde aşağıdaki örnekteki gibi bir sayfa düzeni oluşturulmuştur.

\section{Çevre Sorunu}

Çevre Sorunu

Çevre Sorunu

Çevre Sorunu

Çevre Sorunu

Çevre Sorunu

Çevre Sorunu

Çevre Sorunu

Çevre Sorunu

Çevre Sorunu

Çevre Sorunu

KİT için seçilen anahtar kavramlar: çevre sorunu, çevre koruma, çevre bilinci, biyoçeşitlilik, ekolojik ayak izi, karbon ayak izidir. Testin uygulanması esnasında da, öğrencilerden 30 saniye içerisinde anahtar kavramların akıllarına getirdiği ilgili kavramları yazmaları istenmiştir. Otuz saniyelik zaman dilimi, daha önceki akademik çalışmalarda (Kempa \& Nicholls, 1983; Bahar ve dig, 1999; Bahar \& Özatl1; 2003; Özatlı; 2006; Yalvaç; 2008) yapılan ön testlerde, optimum (en uygun) zaman dilimi olarak belirlendiği için uygun süre olarak alınmıştır. Anahtar kavramın alt alta on defa yazılma nedeni, zincirleme cevap riskini önlemektir. Çünkü öğrenci her kavram yazımında anahtar kavram tekrar dönmezse anahtar kavram yerine cevap olarak yazdığg kavramın aklına getirdiği kelimeleri yazabilir, bu da testin amacına ulaşmasına engel olabilir. Öğrencilere her sayfadaki anahtar kavram için verilen zaman kontrol edilmiştir. Her anahtar kavram için ayrılan sürenin bitiminde öğrencilerden diğer kavrama geçmeleri istenmiş, tüm anahtar kavramlar bitene kadar işleme 
bu şekilde devam edilmiştir. Öğrencilerin tekniğe daha kolay ısınmalarını sağlamak amacı ile testin mantığı ile ilgili bir ön açıklama yapılmış ve esas kavramları yoklamadan önce öğrencilerle kitap, ağaç gibi kavramlara ilişkin birkaç alıştırma yapılmıştır.

Öğrencilere öğretimin bitiminden iki hafta sonra KİT uygulanmıştır. Aynı öğrencilere bir yıl sonra, öğrencilerin 10. sınıfta öğrenim gördükleri yıl aynı tarihte aynı KİT tekrar uygulanmıştır. KİT'ler uygulandıktan sonra, sonuçları değerlendirmek amacı ile her öğrencinin her anahtar kavram için verdiği cevap kavramlar tek tek tespit edilmiştir. Kaç çeşit cevap kelime üretildiği ve bunların hangi anahtar kavramlar için kaç kez tekrar edildiğini gösteren frekans tabloları hazırlanmıştır. Araştırmacılara frekans tablosu hazırlama konusunda yardımcı olması amacı ile öğretim sonrası ve bir yıl sonrasında uygulanan KİT'lere göre oluşturulan frekans tabloları EK 1 ve EK 2'de yer almaktadır. Ancak frekans tablolarının çok uzun olması nedeni ile frekans tablolarının bir kısmı alınabilmiştir. Frekans tabloları dikkate alınarak her iki sonuç için iki ayrı zihin haritası hazırlanmıştır. Zihin haritalarının hazırlanmasında Bahar ve diğerleri (1999) tarafından ortaya konulan Kesme Noktası (K.N.) tekniği kullanılmıştır. Bu tekniğe göre frekans tablosunda, kelime ilişkilendirme testindeki herhangi bir anahtar kavram için en fazla verilen cevap kelimenin 3-5 sayı aşağısı kesme noktası olarak alınmakta ve bu cevap frekansının üstünde bulunan cevaplar haritanın ilk kısmındaki bölüme yazılmaktadır. Daha sonra K.N. belirli aralıklarla aşağıya çekilir ve tüm anahtar kelimeler haritada ortaya çıkıncaya kadar işleme devam edilir. Şekil 1 ve Şekil 2 deki zihin haritaları bu şekilde hazırlanmıştır.

\section{Bulgular ve Yorumlar}

\section{Öğretim sonrası ve bir yıl sonrasında uygulanan KİT Sonuçları}

Tablo 1, Kelime İlişkilendirme Testindeki her anahtar kavram için öğretim sonrası ve bir yıl sonrasında üretilen cevap kelimelerin sayısını göstermektedir. Bu teknikte anahtar kavramlara üretilen cevap kelimelerin sayısı verilerin değerlendirilmesinde kullanılan ilk yöntemlerden biridir (Shavelson, 1974). Öğrencilerin her anahtar kavrama verdikleri kelimelerin sayısı ve niteliği: bellekte anahtar kavramlara verilen cevapların sayısına (cevap olarak verilen kelimeler arttıkça anlamanın da arttığı söylenebilir) ve kelime tipine (anahtar kavram ile ilgili olup olmadığı) bakılarak kavramın anlaşılıp anlaşılmadığı belirlenebilir (Bahar, Nartgün, Durmuş \& Bıçak, 2006). Bu çalışmada öğretim sonrasında uygulanan KİT’te toplam cevap kelime sayısı 396'dır. Öğretimden bir yıl sonra uygulanan 
KİT’te ise 341 olarak tespit edilmiştir. Öğretimden bir yıl sonra öğrencilerin ürettiği cevap kelime sayısındaki azalma, öğrencilerin öğretim sürecinde edindikleri bilgileri zamanla unuttuğu ve bilişsel yapılarında kalıcı değişim sağlanamadığı şeklinde yorumlanabilir.

Tablo 1 Anahtar Kavramlara Verilen Cevap Kelime Sayıları

\begin{tabular}{lcc}
\hline Anahtar Kavramlar & $\begin{array}{c}\text { Kelime Saylsı } \\
\text { Öğretim sonras } 1\end{array}$ & Öğretimden bir yıl sonra \\
\hline Çevre Sorunu & 65 & 65 \\
\hline Çevre Koruma & 59 & 55 \\
\hline Çevre Bilinci & 60 & 56 \\
\hline Biyoçeşitlilik & 89 & 60 \\
\hline Ekolojik Ayak $\dot{\text { zzi }}$ & 63 & 50 \\
\hline Karbon Ayak Izi & 60 & 55 \\
\hline Toplam Cevap Kelime Sayısı & 396 & 341 \\
\hline
\end{tabular}

Tablo 1'de, çevre sorunu anahtar kavramı ile ilgili cevap kelime sayılarında öğretim sonrası ve bir yıl sonrasında değişim yokmuş gibi görünmektedir. Ancak, oluşturulan frekans tablolarında öğretim sonrasında öğrencilerin daha anlamlı ve nitelikli cevap kelimeler yazdığı, bir yıl sonrasında ise daha çok günlük hayatlarında sıkça karşılaştıkları gürültü kirliliği, çöp, araba gibi terimlere yer verdikleri, daha önceki eğitim kademelerinde zihinlerinde yer alan birbirine benzer kavramları birbiri ile ilişkilendirmeden çok sık tekrar ettikleri tespit edilmiştir. Çevre bilinci, çevre koruma, ekolojik ayak izi, biyoçeşitlilik ve karbon ayak izi anahtar kavramları ile ilgili cevap kelime sayılarında da azalma olduğu tespit edilmiştir. Frekans tabloları ve bu tablolara göre oluşturulan zihin haritaları incelendiğinde ise verilen cevap kelimelerin kalitesinin ve anlamlılığının öğretim sonrasında yüksek, öğrencilerin bilgi seviyesindeki azalmanın gerçekte üretilen cevap kelime sayısındaki düşüşten daha fazla olduğu söylenebilir.

Öğretim sonrasında uygulanan KİT’te cevap kelime sayısı çok olsa da cevap kelimelere göre oluşturulan frekans tablosu incelendiğinde öğrencilerin anahtar kavramlar arasında anlamlı ilişkiler kuramadığı, her kavramı birbirinden bağımsız düşündüğü, uygulanan çevre eğitimi ile bilişsel yapılarında önemli bir değişsim sağlanamadığı söylenebilir.

KİT sonuçlarının analizinde anahtar kavramlara verilen cevap kelime çeşitleri ve sayılarının yanı sıra anahtar kavramlara verilen ortak cevap kelimelerin sayısı ve bunların söylenme sırası da önemlidir. Bu da anahtar kelimeler arasındaki anlamsal yakınlığın analiz edilmesini ve bunu haritalamamızı sağlar. Aynı haritalamanın frekans tablosundaki verilerin kullanılarak yapılması da mümkündür. Şekil 1 yöntem kısmında belirtildiği gibi öğretim 
sonrasında uygulanan KİT'in frekans tablosuna göre hazırlanan zihin haritasını göstermektedir.

Şekil 1'de yer alan zihin haritası, Bahar ve diğerlerinin (1999) geliştirdiği kesme noktası tekniğine göre hazırlanmıştır.

\section{KN 25 ve Yukarısı}

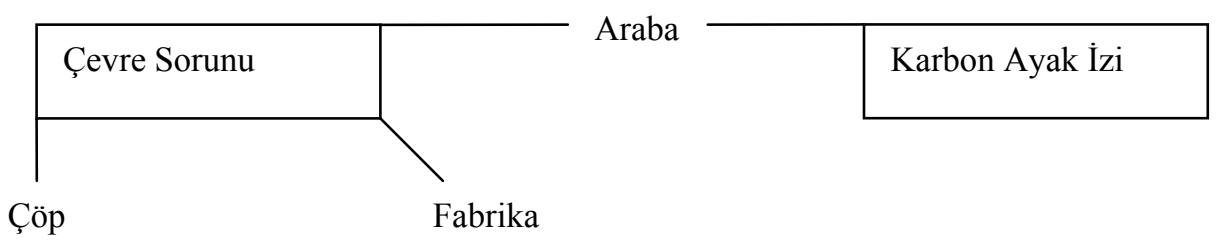

KN 20-24 Arasi

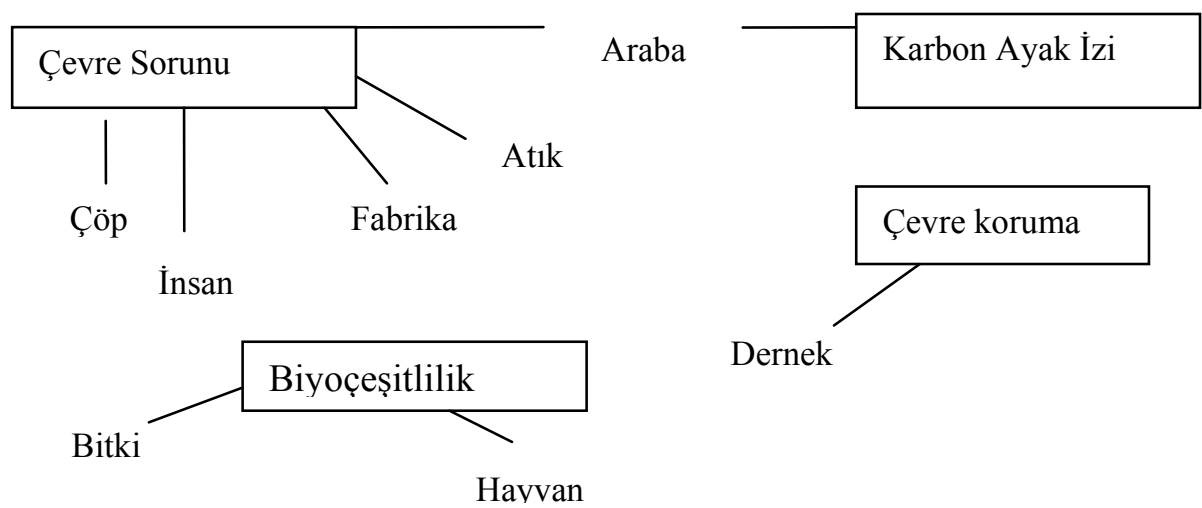

KN 15-19 Arası
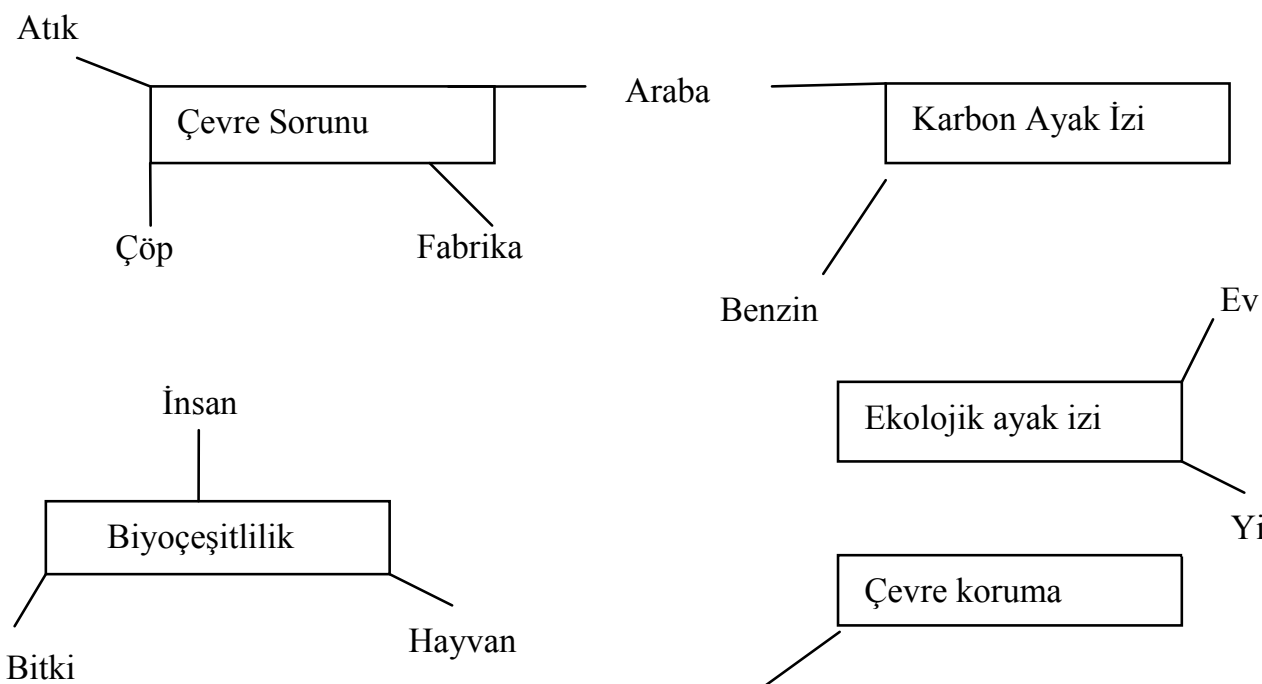

Benzin

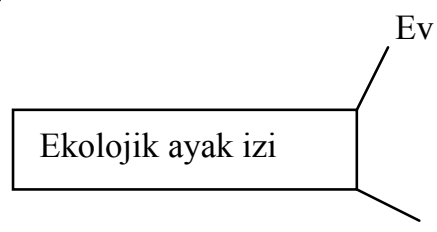

Necatibey Faculty of Education, Electronic Journal of Science and Mathematics Education 


\section{KN 14-10 Arası}

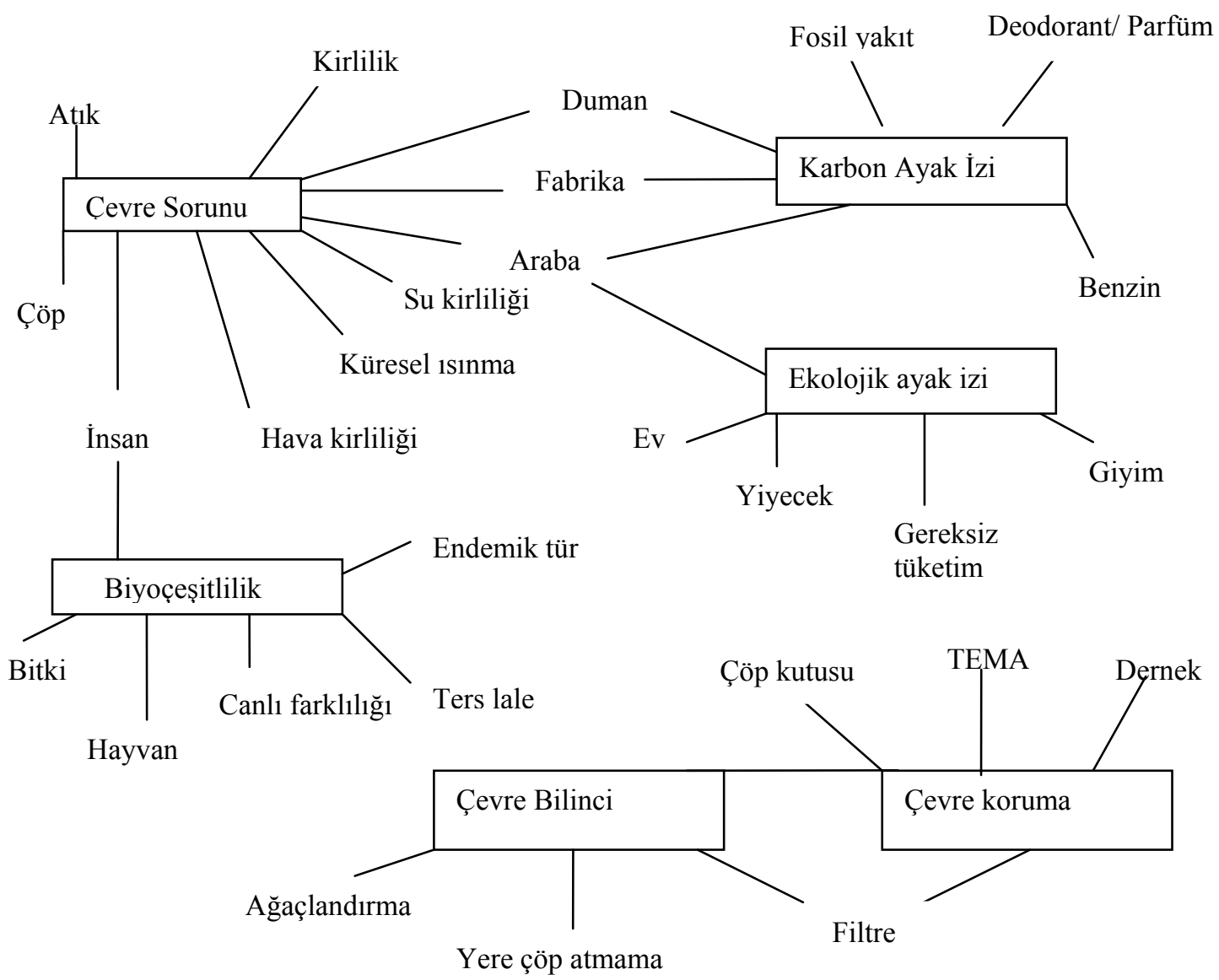

Şekil 1 Öğretim Sonrasında Elde Edilen Zihin Haritası

Şekil 1'de yer alan zihin haritasını değerlendirme:

a) $\mathrm{KN} \geq 25$ seviyesinde öğrencilerin öğretim sonrasında 6 anahtar kavramdan sadece 2'si için cevap oluşturabilmeleri öğretim sonrasında bilgilerinin yetersiz olduğu şeklinde yorumlanabilir. $\mathrm{Bu}$ kesme noktası için hazırlanan frekans tablosunda öğrencilerin çevre sorunu anahtar kavramı için $30 \mathrm{kez}$ fabrika, 28 kez çöp, 27 kez araba cevap kelimelerini ürettikleri tespit edilmiştir. Karbon ayak izini oluşturan faktörlerle ilgili olarak ise sadece $30 \mathrm{kez}$ araba cevap kelimesini üretmişlerdir. Ünite ile ilgili öğretimin yeni yapılmış olmasına rağmen öğrencilerin öğretim sonrasında çevre sorunlarının çeşitleri ile ilgili cevap kelime üretmemeleri ve sadece 3 cevap kelime oluşturmaları bilgi seviyelerindeki artışın yeterli olmadığı şeklinde değerlendirilebilir. Ayrıca çevre 
sorunu ve karbon ayak izi anahtar kavramı arasında doğrudan ilişki kuramadıkları, anahtar kavramları birbirinden bağımsız düşündükleri görülmektedir.

b) KN 20-24 arası için, anahtar kavramlardan dört tanesi açığa çıkmıştır; ancak öğrenciler bu anahtar kavramları birbirinden bağımsız düşünmüsslerdir. $K N \geq 25$ 'te olduğu gibi arabaların hem çevre sorununa yol açtığını hem de karbon ayak izini oluşturan bir faktör olduğunu düşündükleri ve bu doğrultuda ilişki kurdukları, ancak çevre sorunu ile karbon ayak izi arasında direk bir bağlantı kurmadıkları görülmektedir. Karbon ayak izi kavramı ile ilgili yeni bir ilişki kurmamışlardır. Biyoçeşitlilik anahtar kavramı ile ilgili $22 \mathrm{kez}$ bitki ve 23 kez hayvan cevap kelimelerini üretmişlerdir. Her ne kadar biyoçeşitlilik anahtar kavramı ile ilgili ilişkiler kurmuş olsalar da bu ilişkilerin nitelikli olmadığı söylenebilir. Bu kesme noktasında çevre koruma anahtar kavramına yönelik sadece $20 \mathrm{kez}$ dernek cevap kelimesinin üretildiği saptanmıştır.

c) KN 15-19 arası için, 5 anahtar kavramın açığa çıktığı ancak kavramlar arasında yine bağlantı kurmadıkları, her kavramı birbirinden bağımsız düşündükleri görülmektedir. Önceden açığa çıkan anahtar kavramlarla ilgili çok fazla yeni bağlantı kurulamamış, hatta çevre sorunu ve çevre koruma anahtar kavramları ile ilgili yeni cevap kelimeler üretilmemiştir. Ekolojik ayak izi anahtar kavramı ile ilgili 15 kez ev ve 19 kez yiyecek cevap kelimelerinin üretildiği saptanmıştır.

d) KN 10-14 arası için, tüm anahtar kavramların açığa çıktığı, ancak sadece çevre koruma ve çevre bilinci anahtar kavramları arasında adacık oluştuğu, diğer kavramlar arasında bağlantı kurulmadığı, kavramların birbirinden kopuk olduğu görülmektedir. Çevre sorunu ve karbon ayak izi anahtar kavramlarında fabrika ve duman cevap kelimeleri ortak olarak kullanılmış; çevre sorunu, karbon ayak izi ve ekolojik ayak izi anahtar kavramlarında ise araba cevap kelimesi ortak olarak kullanılmıştır. Zihin haritasında dikkat çeken önemli bir nokta ise çevre sorunu, çevre koruma ve çevre bilinci anahtar kavramları arasında öğrencilerin öğretim sonrasında dahi ilişki kuramadıkları, bu kavramlarla ilgili kurdukları ilişkilerin ise zayıf olduğu görülmektedir. Biyoçeşitlilik anahtar kavramı ile ilgili 17 kez insan, 12 kez endemik tür, 14 kez canlı farklılığı, $12 \mathrm{kez}$ ters lale, $12 \mathrm{kez}$ kanguru faresi gibi cevap kelimelerin üretildiği saptanmıştır. Bilimsel açıdan daha anlamlı olan bu cevap kelimelerin daha üst kesme noktalarında açığa çıkmaması, öğrencilerin çoğunluğunun bu bilgilere sahip olmadığı şeklinde yorumlanabilir. Küresel 1sınma gibi önemli 
e) Her ne kadar KN 10-14 arasında tüm anahtar kavramlar açığa çıksa da anahtar kavramlar ile ilgili önemli olan birçok cevap kelimenin öğrenciler tarafından üretilememesi, anahtar kavramlar arasında bağlantılar kurulamaması nedeni ile çevre konuları ile ilgili öğretim sonrasında öğrencilerin bilişsel yapılarındaki değişimin yeterli olmadığı söylenebilir. Öğretim sonrasında öğrencilerin bilişsel yapılarında çevre ve ekoloji konusu ile ilgili kavramlar yer almasına rağmen, kavramlar arasında kurdukları ilişkilerde zayıflık ve eksiklikler olduğu tespit edilmiştir.

Öğretimden bir yıl sonra uygulanan KİT sonuçlarına göre hazırlanan zihin haritası Şekil 2'de verilmiștir.

Çevre sorunu

Hayvan

Biyoçeşitlilik

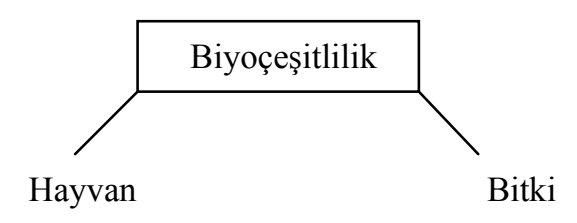




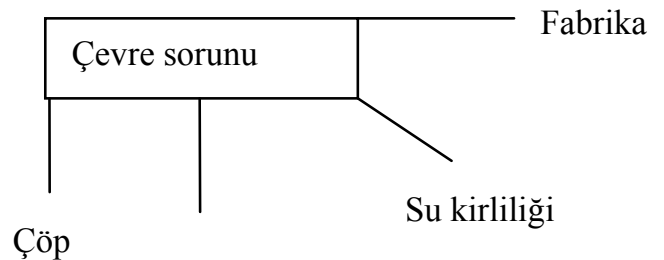

Çöp

Gürültü kirliliği

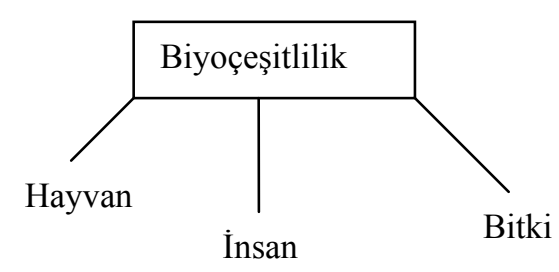

KN 10-14 Arası

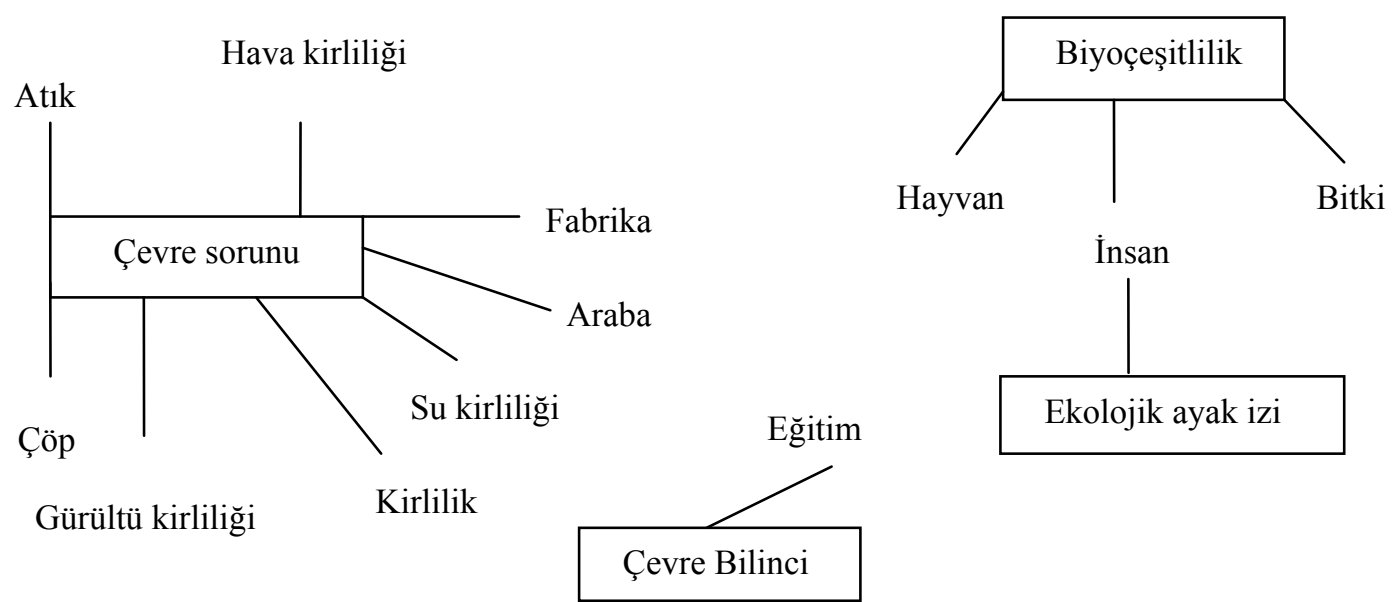

Şekil 2 Öğretimden Bir Y1l Sonra Elde Edilen Zihin Haritas1

Şekil 2'de yer alan zihin haritasını değerlendirme:

a) $\mathrm{KN} \geq 25$ seviyesinde 6 anahtar kavramdan yalnızca bir tanesi açığa çıkmıştır. Öğretim sonrasında uygulanan KİT’te açığa çıkan çevre sorunu ve karbon ayak izi anahtar kavramlarının ve bu kavramlar ile ilişkilendirdikleri cevap kelimelerin bu seviyede açığa çıkmadığı görülmektedir. Açığa çıkan biyoçeşitlilik anahtar kavramı ile ilgili olarak da sadece $28 \mathrm{kez}$ hayvan cevabının üretildiği saptanmıştır. Bu durum, öğrencilerin zaman içerisinde öğretim sırasında edindikleri bilgileri unuttukları, günlük hayatlarında en çok karşılaştıkları canlılar olarak da hayvan cevap kelimesini ürettikleri şeklinde yorumlanabilir. 
b) KN 20-24 arası için, iki anahtar kavramın açığa çıktığı görülmektedir. Biyoçeşitlilik anahtar kavramı ile ilgili yeni cevap kelime olarak 22 bitki kelimesi üretilmiştir. $\mathrm{Bu}$ durum hayvan cevap kelimesinde olduğu gibi öğrencilerin günlük hayatlarında en çok karşılaştıkları canlılardan bahsettikleri şeklinde yorumlanabilir. Bu seviyede açığa çıkan çevre sorunu anahtar kavramı için sadece 20 kez fabrika cevap kelimesinin üretildiği belirlenmiştir. Bu durum öğrencilerin öğretim sonrasında olduğu gibi çevre sorunlarının açığa çıkmasında en önemli faktör olarak fabrikaları gördükleri şeklinde yorumlanabilir. Ancak öğrenciler öğretim sonrası KİT’te çevre sorunu ve fabrika cevap kelimesi arasında 30 kez ilişki kurarken bu sayı bir yıl sonra uygulanan KİT'te 20’ye düşmüştür. Öğretim sonrasında bu seviyede çevre sorunu anahtar kavramı için üretilen çöp, atık, araba kelimelerinin ise açığa çıkmadığı, bu kelimelerle ilişki kuran öğrenci sayısının azaldığı tespit edilmiştir. Yine öğretim sonrasında bu seviyede açığa çıkan karbon ayak izi anahtar kavramı açı̆̆a çıkmamıştır. Bu durum öğrencilerde uygulanan çevre eğitimi sonucunda sahip oldukları bilgilerin kalıcı olmadığı şeklinde yorumlanabilir.

c) KN 15-19 arası için, açığa çıkan anahtar kavram sayısında artış olmadığı yalnızca iki anahtar kavramın açı̆̆a çıktığı tespit edilmiştir. Öğretim sonrasında uygulanan KİT’te ise bu seviyede birbirinden bağımsız dahi olsa beş anahtar kavramın açığa çıktığı ve bu anahtar kavramlar için üretilen cevap kelime sayısının daha fazla olduğu tespit edilmiştir. Çevre sorunu anahtar kavramı ile ilgili öğrencilerin 19 kez su kirliliği, 17 kez çöp, 15 kez gürültü kirliliği cevap kelimelerini ürettikleri saptanmıştır. Öğrencilerin ilişki kurduğu cevap kelimeler incelendiğinde daha çok günlük hayatlarında karşılaştıkları çevre sorunlarından bahsettikleri görülmektedir. Öğretim sonrasında ilk kez bilgi sahibi oldukları ekolojik ayak izi ve karbon ayak izi anahtar kavramlarının ise bu kesme noktasında açığa çıkmadığı tespit edilmiştir. Bu durum öğrencilerin bilişsel yapılarında öğretim sonrasında meydana gelen değişimin kalıcı olmadığı, zamanla öğrencilerin derslerde edindikleri bilimsel bilgileri unutup günlük hayatlarında karşılaştıkları ve yaşadıkları sorunları kavramla ilişkilendirdikleri şeklinde yorumlanabilir. Biyoçeşitlilik kavramı ile ilgili olarak da öğretim sonrasında olduğu gibi öğrencilerin günlük hayatlarında en çok karşılaştıkları canlılar olan bitki, hayvan, insan cevap kelimelerini ürettikleri tespit edilmiştir.

d) KN 10-14 arası için, dört anahtar kavramın açığa çıktı̆̆ı tespit edilmiştir. Öğretim sonrasında uygulanan KİT’te ise bu seviyede tüm anahtar kavramların açığa çıktığı, bu 
kavramlarla ilişkilendirilen kelime sayısının daha fazla ve nitelikli olduğu görülmektedir. Öğretim sonrasında bu seviyede karbon ayak izi kavramının açığa çıktığı; ancak son testte bu anahtar kavramın hiç açığa çıkmadığı tespit edilmiştir. Ekolojik ayak izi anahtar kavramı ile ilgili sadece $10 \mathrm{kez}$ insan cevap kelimesi üretilmiştir. Biyoçeşitlilik anahtar kavramı ile ilgili daha önceki seviyede üretilen cevap kelimeler aynen kalmış, yeni cevap kelime üretilmemiştir. Öğretim sonrasında bu anahtar kavramla ilgili üretilen endemik tür, ters lale, kanguru faresi ve canlı farklılığ1 cevap kelimelerinin üretilmediği, öğrencilerin bu bilgileri unuttuğu söylenebilir. Çevre bilinci anahtar kavramı ile ilgili olarak da sadece 10 kez eğitim cevap kelimesinin üretildiği belirlenmiştir. Bu seviyede, öğrencilerin öğretimden sonra edindikleri bilgileri unuttukları ve sahip oldukları bilgilerin kalıcı olmadığı daha net bir şekilde açığa çıkmaktadır.

e) Öğretimden bir yıl sonra uygulanan KİT’te öğrencilerin kavramları birbiri ile ilişkilendiremedikleri, kavramlar ile ilgili kurdukları ilişkilerin zayıf ve tek yönlü olduğu tespit edilmiştir. Daha önceki eğitim kademelerinde de bilgi sahibi oldukları ve günlük hayatında da karşılaştıkları çevre sorunu ve biyoçeşitlilik anahtar kavramları ile ilgili öğretim sırasında sunulan bilimsel bilgileri unutsalar da günlük hayatlarında yaşadıkları olaylardan yola çıkarak cevap kelimeler üretebildikleri, ancak ilk kez ortaöğretim 9. sınıfta öğrendikleri ekolojik ayak izi ve karbon ayak izi anahtar kavramları ile ilgili edindikleri bilgileri unuttukları ve bu kavramlarla ilgili ilişki kuramadıkları tespit edilmiştir.

\section{Öğretimden Sonra ve Bir Yıl Sonra Elde Edilen Zihin Haritalarının Karşılaştırılması}

> Zihin haritaları KN 25 ve üzeri seviyesinden itibaren incelendiğinde öğretimden sonra elde edilen zihin haritalarının her seviyede hem cevap kelime çeşidi hem cevap kelime sayısı açısından öğretimden bir yıl sonra elde edilen KİT’e üstün olduğu tespit edilmiştir. Her ne kadar öğretimden sonra elde edilen zihin haritalarında öğrencilerin anahtar kavramlarla ilgili ürettikleri cevap kelime sayısı fazla da olsa öğrencilerin anahtar kavramlar arasında ilişki kuramadığı, kavramları birbirinden bağımsız düşündükleri söylenebilir. Zihin haritalarının karşılaştırılmasına göre, uygulanan çevre eğitimi ile öğrencilerin bilişsel yapılarında çevre kavramlarına ilişkin yeterli değişim sağlanamadığı, gerçekleşen değişimin kalıcı olmadığı söylenebilir. 
> Öğretim sonrasına ilişkin zihin haritasına bakıldığında öncelikle günlük hayatta kullanılan anahtar kavramların açığa çıkmasına karşın bunların öğretimden bir yıl sonrasına ilişkin zihin haritasına göre daha bilimsel kavramlarla ilişkilendirildiği göze çarpmaktadır.

> Zihin haritaları aynı kesme noktasında bırakıldığı halde öğretim sonrasında elde edilen zihin haritasında KN 10-14 arasında 6 anahtar kavramın tamamının ortaya çıkmasına karşın öğretimden bir yıl sonra elde edilen zihin haritasında bu seviyede belirtilen kavramların tamamı görülmemektedir. Öğretimden sonra uygulanan KİT’te tüm anahtar kavramların açığa çıkmasına rağmen her iki uygulamada da tam anlamı ile bir ağ oluştuğu söylenemez.

> Öğretimden bir yıl sonra uygulanan KİT sonuçları öğrencilerin anahtar kavramlar ve bunlarla ilgili diğer kavramları birbiri içerisine girmiş bir ağ şeklinde algılayamadıklarını, öğretimden sonra uygulanan KİT sonuçları ise öğrencilerin bilişsel yapısında öğretimden bir yıl sonrasına oranla en azından iki anahtar kavram arasında ara bağlantı oluşturulduğu ve daha fazla cevap kelime bulunduğunu ortaya koymuştur.

\section{Tartışma ve Sonuç}

$\mathrm{Bu}$ çalışmada öğretim sonrası ile bir yıl geçtikten sonra uygulanan KİT sonuçları; öğrencilerin bir yıl sonraki bilgilerinin bilimsel ifadelerden çok günlük hayatlarında karşılaştıkları deneyimlere dayalı olduğunu göstermiştir. Öğretim sonrasında öğrencilerin, bir yıl sonrasına göre daha terimsel ve daha fazla sayıda cevap kelime ürettikleri saptanmıştır. Frekans tablolarına göre hazırlanan zihin haritaları, anahtar kavramlar ve bu anahtar kavramlarla ilişkilendirilen cevap kelimeler ile bunlar arasındaki ara bağlantılar açısından kıyaslandığında; öğretimden bir yıl sonra gerilemenin olduğu, başka bir ifade ile kavramlar hakkında sahip olunan bilgilerin unutulduğu ortaya çıkmaktadır. Zihin haritaları öğrencilerin kavramlar arasındaki ilişkiyi tam bir ağ biçiminde algılamadıklarını göstermiştir.

$\mathrm{Bu}$ çalışmada elde edilen sonuçlar doğrultusunda orta öğretim 9. sınıfta uygulanan çevre eğitimi sonucunda öğrencilerin çevreye ilişkin sahip oldukları bilgilerin yeterli olmadığı söylenebilir. Öğretim sonrasına ilişkin zihin haritası incelendiğinde KN 10-14 aralığında dahi öğrencilerin anahtar kavramlar arasında bağlantı kuramadığı ve anahtar kavramlara ilişkin ürettikleri cevap kelime sayısının az olduğu görülmektedir. Örneğin, 9. sınıf "bilinçli birey yaşanabilir çevre" ünitesinde yer alan ve çevre sorunu anahtar kavramı ile ilişkilendirilmesi 
beklenen ozon tabakasının incelmesi, sera etkisi, radyasyon kirliliği gibi önemli kavramların açığa çıkmadığı görülmektedir. Bunun yanı sıra öğrencilerin öğretim sonucunda sahip oldukları bilgilerin kalıcılığının az olduğu, öğretim sonrasında edindiği bilgileri zamanla unuttukları tespit edilmiştir. Öğretimle edinilen bilgilerin zaman içerisinde belli bir kısmının unutulması beklenilen bir durumdur, ancak öğrencilerin bilgilerindeki azalmanın oldukça fazla olduğu söylenebilir. Örneğin, öğretimden bir yıl sonrasına ilişkin zihin haritası incelendiğinde K.N. 10-14 seviyesinde karbon ayak izi ve çevre koruma anahtar kavramlarının açığa çıkmadığı görülmektedir. Yine bu kesme noktasında ekolojik ayak izi ve biyoçeşitlilik anahtar kavramlarının açığa çıktığı ancak bu kavramlar için üretilen cevap kelime sayısının öğretim sonrasına göre azaldığı görülmektedir. Bu sonuçlar doğrultusunda, uygulanan çevre eğitimi ile öğrencilerin çevre ve çevre sorunlarına bakış açılarında, çevre bilinci ve farkındalıklarında gerçek anlamda kalıcı bir değişim sağlanamadığı söylenebilir. Bu sonuçlar, daha önce alanda yapılan ve ülkemizde uygulanan çevre eğitiminin yeterli olmadığını vurgulayan bilimsel araştırmalara büyük ölçüde benzerlik göstermektedir (Ünal \& Dımışkı, 1999; Bahar, 2000; Özdemir, Yıldız, Ocaktan \& Sarışen, 2004; Yılmaz ve diğerleri, 2002; Özdemir 2007).

$\mathrm{Bu}$ çalışmada kullanılan kelime ilişkilendirme testleri, öğretim sonrası ve bir yıl sonrasında öğrencilerde var olan bilgiyi, kavramsal gelişimin kalıcılığını açığa çıkarmak amacı ile kullanılmıştır. Bulgular literatürde yer alan diğer çalışmalarda olduğu gibi (Shavelson, 2004; Bahar ve dig, 1999; Cardellini \& Bahar, 2000; Bahar \& Özatl1, 2003; Özatl1, 2006; Yalvaç, 2008) bu tekniğin hem bir teşhis hem de bir kavramsal değişim stratejisi olarak fen alanlarında çalışan uzman ve öğretmenlerin kullandığı geleneksel metotlara alternatif bir strateji olabileceği görüşünü desteklemektedir.

Bu çalışmada elde edilen sonuçlar doğrultusunda KİT'in esas olarak bir teşhis ve tanı aracı olarak kullanılmasının uygun olduğu ve öğrencilerin belirli bir süre sonra gerçek öğrenmelerinin ölçülebileceği söylenebilir. Bu konsept sarmal bir müfredat şeklinde Periyodik olarak tekrarlanacağı için Öğretmenler KİT testlerinin sonuçlarını öğrencilerin önceki öğretimlerinden kalan bilgileri tahmin etmek için kullanabilir. Bu durum öğretim öncesi ve sonrası planlamalarına yardımcı olabilir. Söz konusu teknik öğretmenlerin daha büyük gruplara çok kısa sürede ulaşmasını kolaylaştıracaktır. 


\section{Öneriler}

Biyoloji öğretmenleri, çevre/çevre sorunlarına ilişkin kavramlar hakkında öğretim öncesi ve sonrasında öğrencilere KİT uygulaması ile elde edilen zihin haritalarında anahtar kavramlara verilen cevap kelime sayısına (cevap olarak verilen kelime sayısı arttıkça bilişsel yapılarında değişim olduğunu varsayılabilir) ve kelime tipine (anahtar kavramla ilgili olup olmaması) bakarak öğrencilerin kavramlara ilişkin bilişsel yapılarında değişim olup olmadığını kontrol edebilir. Bu şekilde öğretim metotlarını belirleyebilir, öğrencilerin bilişsel yapılarında meydana gelen değişimi daha kısa sürede ve etkili bir şekilde tespit edebilir. 2009 yılında uygulamaya konulan yeni biyoloji müfredatında çevre içerikli üniteler sarmal eğitim modeline uygun olarak her yıl genişletilerek yer almaktadır. Öğrencilerin bir üst öğretim kademesinde çevre konularına ilişkin bilişsel yapılarında meydana gelecek değişim bir önceki kademede oluşan değişimlere ve bu değişimlerin kalıcılığına bağlıdır. Bu nedenle biyoloji öğretmenleri, öğretim öncesinde KİT uygulayıp yeni kavramların öğretimine başlamadan önce elde edilen zihin haritalarını dikkate alarak öğretimde uygulayabilecekleri metotları belirleyebilir, geçmişe dönük eksiklikleri açığa çıkarabilir. Öğretim sonrasında uygulanan KİT ve oluşturulan zihin haritalarına göre; istenilen fakat haritada eksik olan kavramsal bağlantılara yönelebilir. Yeni öğretim yapılanmalarında gereksinim saptamada kullanabilir.

$\mathrm{Bu}$ tekniğin en önemli avantajları, hazırlanmasının kolay olması ve beş dakikalık bir süre içerisinde bireylere veya büyük gruplara kolaylıkla uygulanabilmesidir. $\mathrm{Bu}$ tekniğin dezavantajlarından biri ise öğrencilerin kavramlar arasında kurdukları ilişkilerin sebebi hakkında bir yorum yapılamaması olabilir. Öğrencilerin kavramlar arasında kurdukları ilişkileri zihinlerinde nasıl yapılandırdıkları ve hangi kabullenmelere sahip olduklarını açığa çıkarmaya yönelik KİT tekniği ile birlikte görüşme, kavram haritası gibi teknikler de kullanılabilir. Bu şekilde KİT ile elde edilen bulgular ve ilişkiler daha nitelikli bir şekilde yorumlanabilir. Giriş bölümünde de belirtildiği gibi yapılan bazı bilimsel çalışmalar öğrencilerin kelime ilişkilendirme testlerinde verdiği cevap kelime sayısı ile o konuya ilişkin sınav başarısı arasında olumlu bir ilişki olduğunu göstermiştir. Ancak bu tekniğin sadece bir ölçme aracı olarak kullanılması uygun değildir. Esas olarak bir teşhis ve tanı aracı olarak kullanılması daha uygundur. $\mathrm{Bu}$ nedenle biyoloji öğretmenlerinin bu tekniği öğretim süreçlerinde daha etkili bir şekilde kullanmalarını sağlamak maksadıyla alan uzmanları tarafından hizmet içi eğitimler verilmesinin uygun olacağı düşünülmektedir. 


\section{Kaynakça}

Atasoy, B. (2004). Fen Öğrenimi ve Öğretimi, Ankara: Asil Yayın Dağıtım.

Bahar, M., Johnstone, A.H. \& Sutcliffe, R.G. (1999). Investigation of students' cognitive structure in elementary genetics through word association tests. Journal of Biological Education, 33, 134-141.

Bahar, M. (2000). Üniversite öğrencilerinin çevre eğitimi konularındaki ön bilgi düzeyi, kavram yanılgıları. V. Uluslararası Ekoloji ve Çevre Sorunları Sempozyumu (12Kasım) Tübitak, Ankara.

Bahar, M. \& Özatlı, N.S. (2003). Kelime İletişim Test Yöntemi ile Lise 1. Sınıf Öğrencilerinin Canlıların Temel Bileşenleri Konusundaki Bilişsel Yapılarının Araştırılması. BAÜ Fen Bil. Enst. Dergisi, 5.2, 75-85.

Bahar, M., Nartgün, Z., Durmuş, S. \& Bıçak, B. (2006). Geleneksel-alternatif ölçme ve değerlendirme ögretmen el kitabl, Ankara: Pegem Akademi.

Cardellini, L. \& Bahar, M. (2000). Monitoring the learning of chemistry through word association tests. Australian Chemistry Resource Book, 19, 59-69.

Doğan, M. (1997), DPT, Ulusal Çevre Eylem Planı: Eğitim ve Katılım, Türkiye Çevre Vakfi.

İnanç, N. \& Kurgan, E. (2000). Çevre eğitimi ve halkın bilinçlendirilmesi. V. Uluslar arası Ekoloji ve Çevre Sorunları Sempozyumu: Çevre Eğitimi, Ankara, 1-2 Kasım.

Keleş, R. (1997), Insan Çevre Toplum, İmge Kitapevi.

Kempa, R.F. \& Nicholls, C.E. (1983) .Problem solving ability and cognitive structure - an explanatory investigation. European Journal of Science Education, 5, 171-184.

Shavelson, R. J. (1974) Methods for examining representations of a subject-matter structure in a student's memory. Journal of Research in Science Teaching, 11, 231249.

Özdemir, O., Yıldız, A., Ocaktan, E. \& Sarışen, Ö. (2004). Tıp Fakültesi Öğrencilerinin Çevre Sorunları Konusundaki Farkındalık ve Duyarlılıkları. Ankara Üniversitesi Tıp Fakültesi Mecmuası, 57(3), 117-127.

Özatlı, N. S. (2006). Öğrencilerin Biyoloji Derslerinde Zor olarak Algıladıkları Konuların Tespiti ve Boşaltım Sistemi Konusundaki Bilişsel Yapılarının Yeni Teknikler ile Ortaya 
Konması. Yayınlanmamış Doktora Tezi, Balıkesir Üniversitesi Fen Bilimleri Enstitüsü Biyoloji Eğitimi Anabilim Dalı, Balıkesir.

Özdemir, O. (2007) Yeni Bir Çevre Eğitimi Perspektifi: “Sürdürülebilir Gelişme Amaçlı Eğitim", Education and Science, 32 (45), 23- 39.

Tombul, F. (2006). Türkiye'de Çevre için Eğitime Verilen Önem. Yayınlamamış Yüksek Lisans Tezi, Ankara Üniversitesi sosyal Bilimler Enstitüsü Sosyal Bilimler Çevre Anabilim Dalı, Ankara

Ünal, S. \& Dımışkı, E. (1999). Üniversite öncesi çevre eğitimi ve sorunları, T.C. Çevre Bakanlığ Çevre ve İnsan Dergisi, 42-56.

Yalvaç, G. H. (2008). İşbirlikli Öğrenme Yaklaşımının Öğretmen Adaylarının Çevreye İlişkin Zihinsel Yapılarına Etkisi. Yayınlanmamış Yüksek Lisans Tezi, Abant İzzet Baysal Üniversitesi Sosyal Bilimler Enstitüsü İlköğretim ana bilim Dalı Fen ve Teknoloji Öğretmenliği Bilim Dalı, Bolu.

Yılmaz, A., Morgil, İ., Aktuğ, P. \& Göbekli, İ. (2002). Ortaöğretim ve Üniversite Öğrencilerinin Çevre Kavramları ve Sorunları Konusundaki Bilgileri ve Öneriler. Hacettepe Üniversitesi Ĕ̈itim Fakültesi Dergisi, 22, 156-162.

White, R. T. \& Gunstone, R. F. (2000). Probing understanding. The Falmer Press. 


\section{EK 1 Öğretimden Sonra Elde Edilen KİT Frekans Tablosu}

Anahtar kavramlar: 1- Çevre sorunu 2- Çevre Koruma 3- Çevre Bilinci 4- Biyoçeşitlilik

5- Ekolojik ayak izi 6- Karbon ayak izi

\begin{tabular}{|c|c|c|c|c|c|c|}
\hline Cevap kelimeler & 1 & 2 & 3 & 4 & $\overline{5}$ & 6 \\
\hline Çevre sorunu & --- & --- & --- & --- & --- & --- \\
\hline Çevre koruma & --- & 3 & 9 & --- & --- & --- \\
\hline Çevre bilinci & --- & 13 & --- & --- & --- & --- \\
\hline Biyoçeşitlilik & --- & --- & --- & --- & --- & --- \\
\hline Ekolojik ayak izi & --- & --- & --- & --- & --- & --- \\
\hline Karbon ayak izi & --- & --- & --- & --- & --- & --- \\
\hline Fabrika & 30 & 2 & 1 & --- & 4 & 10 \\
\hline Çöp & 28 & 2 & --- & --- & 8 & 1 \\
\hline Teknoloji & 1 & --- & --- & --- & --- & -- \\
\hline Görüntü kirliliği & 10 & --- & --- & --- & --- & -- \\
\hline Araba & 27 & --- & 2 & --- & 14 & 30 \\
\hline Yangin & 5 & --- & --- & --- & 1 & 2 \\
\hline Pislik & 1 & --- & --- & --- & -- & -- \\
\hline Bina & 2 & --- & --- & --- & --- & --- \\
\hline Yă̆ atı̆̆1 & 3 & --- & 1 & --- & --- & -- \\
\hline Cif & 1 & --- & --- & --- & --- & --- \\
\hline Çamaşır suyu & 1 & --- & --- & --- & --- & -- \\
\hline Soba & 1 & --- & --- & --- & --- & 3 \\
\hline İş makinesi & 2 & --- & --- & --- & --- & 2 \\
\hline Kurşunlu benzin & 1 & --- & --- & --- & --- & --- \\
\hline Sera gazı & 3 & --- & --- & --- & --- & --- \\
\hline Duman & 10 & --- & --- & --- & --- & 12 \\
\hline Kirlilik & 11 & --- & --- & --- & 2 & 1 \\
\hline Nükleer enerji & --- & --- & --- & --- & -- & 2 \\
\hline Kaza & --- & --- & --- & --- & --- & 2 \\
\hline Radyasyon & 3 & --- & --- & --- & --- & -- \\
\hline Kimyasal madde & 5 & --- & 1 & --- & --- & 1 \\
\hline Gıda kirliliği & 1 & --- & --- & --- & --- & --- \\
\hline İlaç & 2 & --- & --- & --- & --- & --- \\
\hline Çim & 1 & --- & --- & --- & --- & --- \\
\hline İnsan & 10 & 2 & 2 & 17 & 4 & 1 \\
\hline Sigara & 5 & --- & 1 & --- & -- & 1 \\
\hline Plastik & 5 & --- & 1 & --- & 1 & --- \\
\hline Motor & 2 & --- & --- & --- & -- & 2 \\
\hline Uçak & 1 & --- & --- & --- & 4 & 7 \\
\hline Ev & 2 & --- & --- & --- & -- & 2 \\
\hline Atık & 17 & 4 & 2 & --- & 4 & 3 \\
\hline Küresel 1sınma & 10 & --- & --- & --- & --- & 2 \\
\hline
\end{tabular}




\section{EK 2 Öğretimden Bir Yıl Sonra Elde Edilen KİT Frekans Tablosu}

Anahtar kavramlar: 1- Çevre sorunu 2- Çevre Koruma 3- Çevre Bilinci 4- Biyoçeşitlilik 5- Ekolojik ayak izi 6- Karbon ayak izi

\begin{tabular}{|c|c|c|c|c|c|c|}
\hline Cevap kelimeler & 1 & 2 & 3 & 4 & 5 & 6 \\
\hline Çevre sorunu & --- & --- & --- & --- & --- & --- \\
\hline Çevre koruma & --- & & 3 & --- & --- & --- \\
\hline Çevre bilinci & --- & 1 & --- & --- & --- & --- \\
\hline Biyoçeşitlilik & --- & --- & --- & --- & --- & --- \\
\hline Ekolojik ayak izi & --- & --- & --- & --- & --- & --- \\
\hline Karbon ayak izi & --- & --- & --- & --- & --- & --- \\
\hline Fabrika & 20 & --- & --- & 1 & 1 & 3 \\
\hline Su kirliliği & 19 & --- & --- & --- & --- & --- \\
\hline Hava kirliliği & 14 & --- & --- & --- & --- & --- \\
\hline Çöp & 17 & --- & --- & --- & 2 & --- \\
\hline Araba & 10 & --- & --- & --- & 5 & 4 \\
\hline Egzoz & 9 & --- & --- & --- & --- & 3 \\
\hline İnsan & 5 & 3 & 3 & 18 & 10 & 2 \\
\hline Kirlilik & 11 & --- & --- & --- & 1 & --- \\
\hline Gazlar & 2 & 1 & --- & --- & --- & --- \\
\hline Duman & 5 & --- & --- & --- & --- & 4 \\
\hline Pislik & 1 & --- & --- & --- & 1 & --- \\
\hline Koku & 1 & --- & --- & --- & --- & --- \\
\hline Çevre & 1 & --- & --- & --- & --- & --- \\
\hline At1k & 12 & --- & --- & --- & 4 & 4 \\
\hline Ter & 1 & --- & --- & --- & --- & --- \\
\hline Bilinçsizlik & 1 & --- & --- & --- & --- & --- \\
\hline Sanayi & 7 & --- & --- & --- & --- & --- \\
\hline Kamyon & 1 & --- & --- & --- & --- & 1 \\
\hline Dünya & 1 & --- & --- & --- & 1 & --- \\
\hline Apartman & 1 & --- & --- & --- & 3 & --- \\
\hline Mevsim & 1 & --- & --- & --- & --- & --- \\
\hline Gürültü kirliliği & 15 & --- & --- & --- & --- & --- \\
\hline Doğa & 1 & --- & --- & --- & --- & --- \\
\hline Zehirli madde & 1 & --- & --- & --- & --- & --- \\
\hline Sigara & 3 & --- & --- & --- & --- & 1 \\
\hline Telefon & 1 & --- & --- & --- & --- & --- \\
\hline Görüntü kirliliği & 1 & --- & --- & --- & --- & --- \\
\hline Meteor & 1 & --- & --- & --- & --- & --- \\
\hline Toprak kirliliği & 4 & --- & --- & --- & --- & --- \\
\hline Hayvan & 3 & --- & --- & 28 & 4 & 1 \\
\hline Dünyanın sonu & 1 & --- & --- & --- & --- & --- \\
\hline Verimsizlik & 2 & --- & --- & --- & --- & --- \\
\hline Küresel ısınma & 7 & --- & --- & 1 & --- & 2 \\
\hline Mikrop & 1 & --- & --- & --- & --- & -- \\
\hline
\end{tabular}

